\title{
Teachers' Misconception about National Assessment and National Examination
}

\author{
1Kisno, ${ }^{2}$ Umi Rokhyati, ${ }^{3}$ Fenty Nur Fatimah, ${ }^{4}$ Rita M. Siregar \\ Email : ${ }^{1}$ kisno.shinoda@stami.ac.id, ${ }^{2}$ umi.rokhyati@pbi.uad.ac.id, 3 fentynurfatimah31@gmail.com, \\ ${ }^{4}$ ritasiregar7277@gmail.com \\ 1,3 Sekolah Tinggi Akuntansi dan Manajemen Indonesia, ${ }^{2}$ Universitas Ahmad Dahlan, Yogyakarta, \\ Indonesia, ${ }^{4}$ Universitas HKBP Nommensen Pematangsiantar, Indonesia
}

\section{ARTICLE INFO}

Article history

Received: 19 February 2021

Revised: 5 March 2021

Accepted: 10 March 2021

Keywords

teachers' misconception

national assessment

national examination

\section{ABSTRACT}

National Assessment is administered as the new policy from The Ministry of Education and Culture of Indonesia. It will be administered from September to October 2021. Therefore, teachers are urged to master the concept and the format of national assessment so as to implement it in the learning process. The teachers' proper understanding on those concept and formats supports the success of national assessment. Despite this fact, most of the teachers were fulfilled with anxiety of the transition from national examination to national assessment. This research attempted to reveal the junior high school teachers' misconception about National assessment and national examination. A 30-online-multiple-choice test was administered to 50 in-service teachers from both the state and the private junior high schools. The data was analyzed using descriptive statistics. The findings revealed that both the state and the private junior high schools' teachers experienced three misconceptions about national assessment. Majority of the teachers' misconception was about the technical administration of national assessment $(76 \%)$ and the others were about the basic concept of national assessment $(65 \%)$, and the follow up to result of national assessment (61\%). These results suggest the reinforcement and empowerment of the schools concerning the socialization and the prototype or simulation implementation of national assessment.

This is an open access article under the CC-BY-SA license.

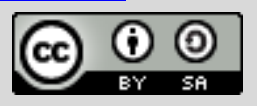

\section{Introduction}

Education holds an essential factor in facing time changes especially in industrial revolution period or 4.0 era. Most sectors of human life in 4.0 era are now disrupted with super rapid changes due to the quick access to information and technology. Education itself is disrupted with the intervention of sophisticated technologies that are easily found in daily life. The existence of corona virus pandemic by the end of 2019 has given more variable to disruption in education sector. Even though education is still a substantial role, it has now been in crisis throughout the 
world. Schools around 190 countries are closed and education through teaching and learning processes has been converted to online mode using internet, television, or radio (Unicef, 2020). Indonesia is one of the countries forcefully administering online education due to corona virus outbreak. Many head of regional areas decided to instruct schools and offices were carried out from home. Finally, on August 2020, the government issued a new policy about the administration of education through a joint decree of four ministers. This policy is only one of many educational policies that have been changed in Indonesia.

The policy of education in Indonesia has experienced some changes from one period to another period. This phenomenon emphasizes a negative opinion that every minister change determines policy change. A change is something that is unavoidable and in education sector, change is acceptable due to time and situation. Moreover, disruptions occurred in 4.0 era compel a nation to change its educational directions and policy. For example, since the independence of Indonesia in 1945 until 2013, Indonesia has reformed its curriculum for ten times (Ritonga, 2018; Iramdan \& Manurung, 2019). These curriculum changes influenced the way how schools stipulated the passing criteria for their students. There were totally eight changes of schools' graduation system in Indonesia since 1950 as is listed in Table 1.

Table 1. Examination reform in Indonesia

\begin{tabular}{|l|l|l|l|}
\hline No & \multicolumn{1}{|c|}{ Period } & \multicolumn{1}{|c|}{ Graduation System } & \multicolumn{1}{c|}{ Characteristics } \\
\hline 1 & $1950-1964$ & $\begin{array}{l}\text { Final Examination or } \\
\text { "Ujian Penghabisan" }\end{array}$ & National scale, determining passing criteria \\
\hline 2 & $1965-1971$ & $\begin{array}{l}\text { State Examination or } \\
\text { "Ujian Negara" }\end{array}$ & $\begin{array}{l}\text { National scale, passing grade 6 points for every } \\
\text { subject }\end{array}$ \\
\hline 3 & $1972-1979$ & $\begin{array}{l}\text { School Examination or } \\
\text { "Ujian Sekolah" }\end{array}$ & $\begin{array}{l}\text { School-based examination, high quantity graduates, } \\
\text { but quality is questionable }\end{array}$ \\
\hline 4 & $1980-2002$ & $\begin{array}{l}\text { Final National Learning } \\
\text { Evaluation or "Ebtanas" }\end{array}$ & $\begin{array}{l}\text { National-scale, high quantity graduates, but } \\
\text { learning achievement is relatively low }\end{array}$ \\
\hline 5 & $2003-2004$ & $\begin{array}{l}\text { Final National } \\
\text { Examination or "Ujian } \\
\text { Akhir Nasional" }\end{array}$ & $\begin{array}{l}\text { To determine passing criteria, map national } \\
\text { education quality, and continue to higher education }\end{array}$ \\
\hline 6 & $2005-2013$ & $\begin{array}{l}\text { National Examination or } \\
\text { "Ujian Nasional" }\end{array}$ & $\begin{array}{l}\text { To determine passing criteria, map national } \\
\text { education quality, and continue to higher education }\end{array}$ \\
\hline 7 & $2014-2020$ & $\begin{array}{l}\text { Computer-Based national } \\
\text { National Examination or } \\
\text { "Ujian Nasional Berbasis } \\
\text { Komputer" }\end{array}$ & $\begin{array}{l}\text { To determine passing criteria, map national } \\
\text { education quality, and continue to higher education }\end{array}$ \\
\hline 8 & $2021-$ present & $\begin{array}{l}\text { National Assessment or } \\
\text { Asesmen Nasional }\end{array}$ & $\begin{array}{l}\text { Not determining passing criteria, mapping national } \\
\text { education, consists of Minimum Competency } \\
\text { Assessment, Character Survey, and Learning } \\
\text { Environment Survey }\end{array}$ \\
\hline
\end{tabular}

Source: (Hartanto, 2013) (Kompas, 2020)

Based on Table 1, Indonesia finally changed the format of examination after 64 years where paper-based examination was replaced by computer-based examination in 2014. This indicates the change in the education system due to the advance of technology. However, the change was 
essentially in format but not in the nature of the assessment. Despite the computerized test, the examination itself was still in the spirit of national examination. The main aim of national examination was to determine the students' graduation. This caused some negative effects for both students and teachers such as the feeling of under pressure, anxiety, fear, and dismay (Alawiyah, 2015). National examination also caused other critics such as answer key leakage, and deceptional behavior by teachers, students, or proctors (Hartanto, 2013; Hadi \& Arwan, 2011). Apart from that, national examination administered with computer-based led to another problem such as the students' capability in comprehending the questions (Pernamawati, Kritiawan, \& Fitria, 2021; Romios, Kristianingrum, \& Saragih, 2020). The other problem of computer-based examination was the incompleteness of facilities such as computer, electricity, and internet connection in every school (Ismail, 2015). Finally, based on the minutes of a closed meeting about national examination dated 24th March 2020, the national examination was stopped in 2021 for the reason of Covid-19 pandemic. The judicial basis of this regulation was issued in a circular letter of The Minister of Education and Culture No. 4 year 2020 about the implementation of education policies in an emergency period of Corona Virus Disease outbreak (Koesoema, 2020).

The new policy from the Minister of Education and Culture stipulates National Assessment in 2021. In the beginning, this assessment was planned to administer on March to April 2021. However, considering the readiness and the anticipation to the relatively increasing pandemic number, national assessment is rescheduled from September to October 2021. This postponement gives an opportunity for school to "breathe freely". However, schools and teachers experienced anxiety on facing the national assessment before and during this spare time. Some schools have carried out extra courses and some teachers have been busy purchasing books related to national assessment since they are afraid of preparing their students to pass the assessment. These facts of course are not pursuant to the spirit of the national assessment, which aims to measure general capabilities through reading literacy and numerical literacy. Further, this assessment also includes character survey and learning environment survey which are taken by students, teachers, and headmasters (Kemdikbud, 2020).

Studies about national assessment are limited to pre-service teachers and students' knowledge and perception (Novita, Mellyzar, \& Herizal, 2021; Ningsih, Shara, Andriani, \& Kisno, 2021; Munthe, 2020). In spite of this, none of those researches studied about the in-service teachers' knowledge and readiness in facing national assessment. This study purposes to reveal the junior high school teachers' misconception about national assessment and national examination. This study is expected to give a clear description on how in-service teachers 
prepare themselves through the knowledge of basic concept, technical administration and the follow-up concerning the result of national assessment.

\section{Method}

An-online objective test consisting of three subtopics of national assessment was administered to 50 in-service teachers. There were 25 teachers from state and private junior high school respectively and they were given an online multiple-choice test via Google Form. The questions were taken from "Guru Belajar Seri AKM SMP" (an online training for teachers) intending to deepen their knowledge about national assessment. This internet-connected training was made available by the Ministry of Education and Culture and adapted by the researchers. Each test consisted of 10-item-statement and the teachers opted True or False based on the given statement. The subtopics of the test is described in Table 2.

Table 1. Questions on national assessment

\begin{tabular}{|c|c|c|c|}
\hline \multirow[b]{2}{*}{ Item No } & \multicolumn{3}{|c|}{ Subtopics } \\
\hline & Basic Concept & $\begin{array}{c}\text { Technical } \\
\text { Administration }\end{array}$ & Follow Up Result \\
\hline 1 & $\begin{array}{l}\text { Consequence on students' } \\
\text { graduation }\end{array}$ & Form of questions & Aim of Reporting \\
\hline 2 & $\begin{array}{l}\text { National Assessment as the } \\
\text { substitution to National } \\
\text { Examination }\end{array}$ & $\begin{array}{l}\text { Characteristics of } \\
\text { Questions }\end{array}$ & Lesson Design \\
\hline 3 & $\begin{array}{l}\text { Competence and Content } \\
\text { Emphasis }\end{array}$ & $\begin{array}{l}\text { Components of National } \\
\text { Assessment }\end{array}$ & $\begin{array}{l}\text { Competence-Based } \\
\text { Learning }\end{array}$ \\
\hline 4 & $\begin{array}{l}\text { Cognitive Aspects of } \\
\text { National Assessment }\end{array}$ & Mode of questions & $\begin{array}{l}\text { Characteristics of } \\
\text { Competence-Based } \\
\text { Learning }\end{array}$ \\
\hline 5 & Technical Aspects & Assessment Takers & $\begin{array}{l}\text { Challenge for Competence- } \\
\text { Based Learning }\end{array}$ \\
\hline 6 & School Strategy & $\begin{array}{l}\text { School Level Assessment } \\
\text { Takers }\end{array}$ & $\begin{array}{l}\text { Competence and Content } \\
\text { Emphasis }\end{array}$ \\
\hline 7 & Students' Motivation & Aim of Assessment & Significance of Reporting \\
\hline 8 & $\begin{array}{lcc}\text { Aim of } & \text { National } \\
\text { Assessment } & \\
\end{array}$ & Period of Assessment & Competence Definition \\
\hline 9 & $\begin{array}{l}\text { National Assessment is not } \\
\text { National Examination }\end{array}$ & Stimulant of Questions & $\begin{array}{l}\text { Characteristics } \\
\text { Competence-Based } \\
\text { Learning }\end{array}$ \\
\hline 10 & $\begin{array}{l}\text { Measurement of National } \\
\text { Assessment }\end{array}$ & Design of Questions & Students' achievement \\
\hline
\end{tabular}

By implementing quantitative research design, the data was then analyzed with descriptive statistics. This design allows the researchers to sum up the entire distribution of scores into simple numbers (Bordens \& Abbott, 2018). The number of the teachers answering more than 5 items was considered "pass" and those answering less were "failed". The researchers then calculated the summary of the number of the teachers passing the minimum score and averaged it into a percentage representing the number of respondents. 


\section{Discussion}

\section{Teachers' Misconception of National Assessment Basic Concept}

Figure 1 below depicts the percentage of in-service teachers answering the questions related to the basic concept of national assessment.
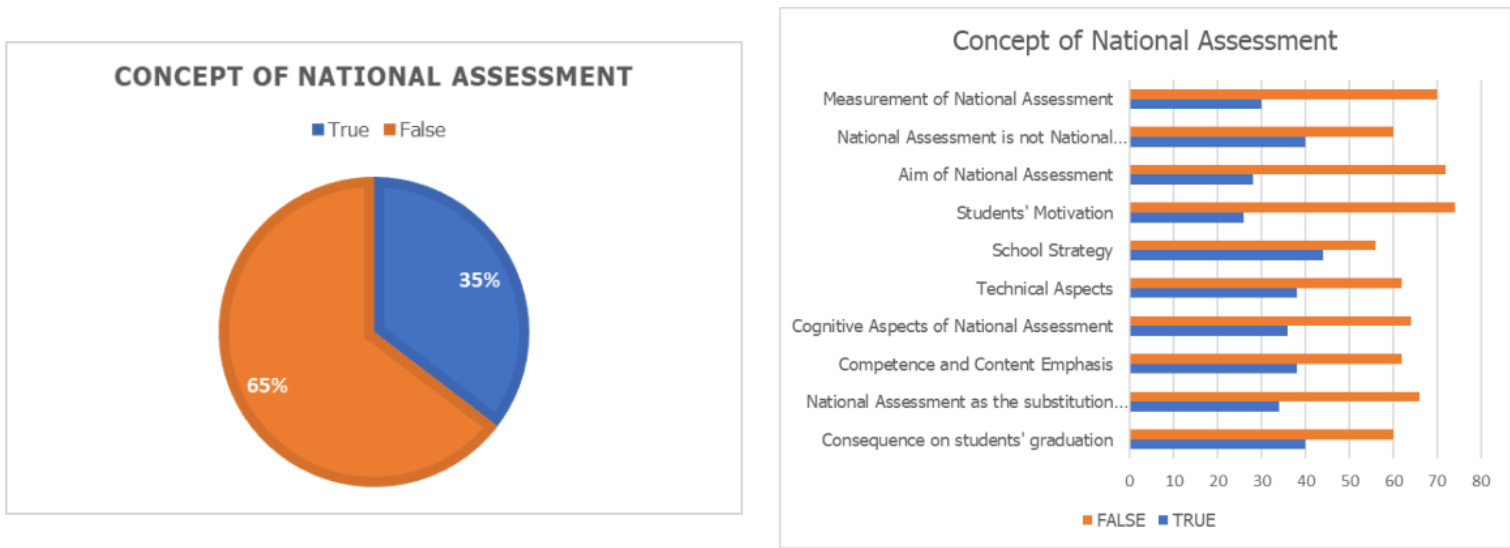

Figure 1. Percentage of national assessment basic concept

It can clearly be seen that the number of teachers answering incorrect is more dominant than those passing the minimum score. In the aspect of aim of national assessment, the teachers considered that this assessment was implemented to determine the passing criteria of the students. In other words, the consequence of not passing the assessment will lead to a negative effect on the students' graduation. Whereas, the aim of national assessment is to evaluate the quality of education system throughout Indonesia (Kemdikbud, 2020). Most of the teachers regarded national assessment and national examination identically evaluate the students' individual achievement. This misconception is related to the further issue about the students' motivation. The teachers thought that the students would be demotivated when the aim of national assessment was not used as the passing criteria while using passing criteria as a threat (Effendi \& Suyudi, 2017; Sutari, 2017) results in a negative effect for the students' character. That is to say, the students will only be motivated to achieve good grades instead of good way of learning. However, the most important thing is to form the character of the students to be longlife learners. It takes years to grow persistence as the part of the students' character. This is in accordance with the study stating that the character learning aspect is still the essence of formation of character (Hidayati, Zaim, Rukun, \& Darmansyah, 2014).

Then, the teachers considered that the cognitive aspects tested in national assessment and national examination were similar. It is true that both examine cognitive aspects, but those aspects were not tested in particular subjects. Reading literacy and numerical literacy becomes the focus of cognitive aspects in national assessment (Kemdikbud, 2020). The decision to include reading literacy and numerical literacy was based on the Indonesian students' PISA score that 
decreased from 2015 until 2018. During this three-year period, reading literacy of the students of Indonesia experienced a sharp decrease and this is why reading literacy is regarded as the most essential part to master in Minimum Competency Assessment (Shara, Andriani, Ningsih, \& Kisno, 2020). Both reading literacy and numerical literacy are basic general capabilities and are related to thinking ability with language and mathematics in some contexts. The teachers incorrectly understood this concept that other subjects excluding language and mathematics were not important. In other words, teachers assumed that the content of a lesson was more important than the competency. Minimum Competency Assessment as the part of national assessment measures the minimum competence of a learner to live productively amidst society. This is closely related to the schools through their teachers' strategy in learning process. Teacher-centered learning does not have a comprehensive impact to the students' competence and teachers' creativity is required in the learning innovation (Nehru, 2020). However, the teachers' creative way of teaching is only focused on the thinking competence. It does not mean that reading literacy and numerical literacy cannot be developed in every subject in the curriculum. Innovative way such as creative classroom management, selection of contextual material, and the use of humor or storytelling (Asrianto, Rohmayadevi, \& Rokhyati, 2020) support the activity of reading literacy and numerical literacy in the classroom.

The minimum competency of the students is closely related to the integration of learning process to the life skills. The test result found that teachers tended to focus on the content of his or her own subject without linking it to the real-life skill and to the other subjects. It is no wonder why the competency of a subject is separated to the others. Whereas, the activity in integrated learning occurs in a real way, links a concept to the other concept, and focuses on the students' learning experience to be more meaningful (Akib, et al., 2020). This is consistent with a study concluding that to achieve the minimum competency is started from the basic conceptual understanding of a topic which applies integrative learning (Widyatmoko \& Shimizu, 2018). Thus, the integration of reading literacy and numerical literacy can be implemented in all subjects studied in Junior High School level. Once again, this requires teachers' creative thinking and collaboration. The existence of collaborative learning, project-based learning, problembased learning, and inquiry learning is in vain when it does not come into implementation.

\section{Teachers' Misconception of National Assessment Technical Administration}

The highest percentage of the teachers' misconception was found in technical administration section. Figure 2 illustrates the highest percentage of the teachers' misconception in administering the national assessment technically. 

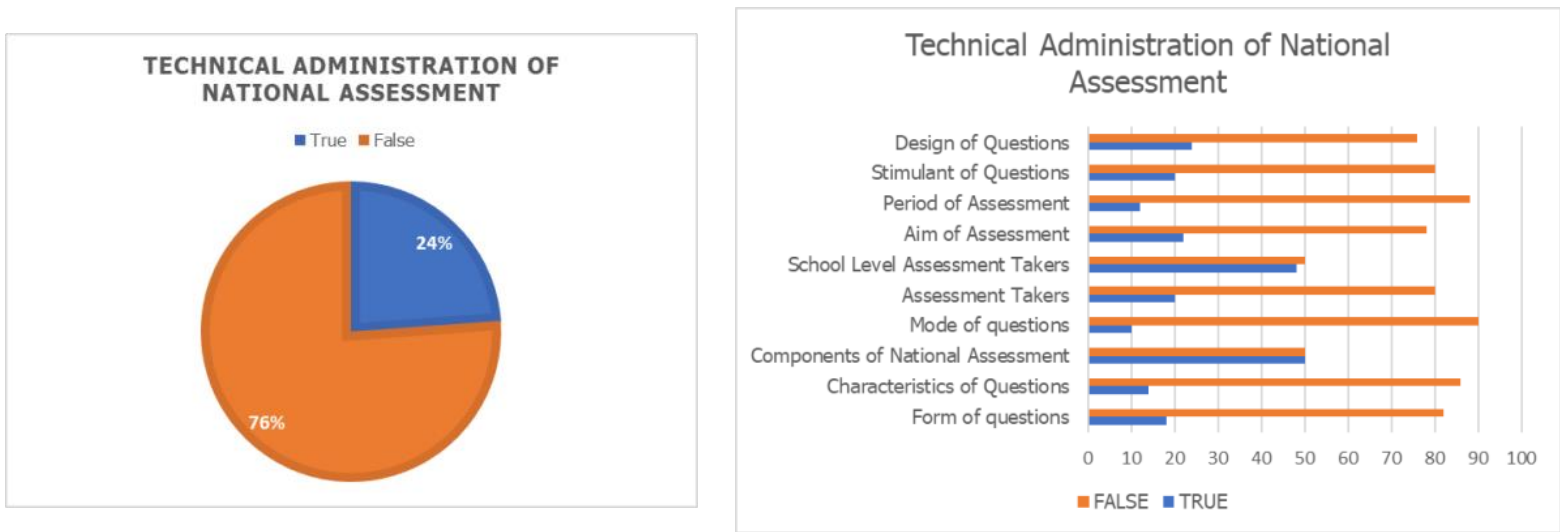

Figure 2. Percentage of national assessment technical administration

First, most of the teachers were not familiar with the format of the question. They deemed that the questions in national assessment were in multiple choice or essay as was found in the national examination. Multiple choice and essay are still used in national assessment with the addition of other type of questions such as complex multiple choice, cloze test, and matching (Kemdikbud, 2020). That is to say, there are totally five question formats existing in national assessment. The teachers often used multiple choices with a single correct answer and essay in their assessment. It could be stated that only two out of five questions formats that have been implemented in the learning process. The familiarization of this question format is believed to support the adaptation of both teachers and students in order to answer the questions in the national assessment. The more frequent the implementation of those question types, the more familiar and adaptable the teachers and students will be.

Second, the questions they had in their mind were those that were long and difficult. The teachers did not have any idea how to design HOTS questions and this caused the misleading to how a question is designed since higher order thinking skills is not identical to level of difficulties. The basic concept of the questions in national assessment is related to Higher Order Thinking Skills (HOTS). The characteristics of HOTS questions are: (1) Measuring higher thinking skills; (2) Landing the basis on contextual problem; and (3) Implementing various question forms (Widana, 2017). The teachers were supposed to train themselves to create HOTS questions since there were many modules and guidance of how to design such questions. This is related to the teachers' motivation in self-capacity building for professional development. The teachers will not be able to instruct their students to solve HOTS questions unless the teachers themselves are able to design the questions properly. This is in accordance with a research stated that the use of HOTS as an assessment instruments could help students train their higher order thinking skill (Kusuma, Rosidin, Abdurrahman, \& Suyatna, 2017; Yuliati \& Lestari, 2018).

Third, the teachers still believed that the final-year students mandatorily took the national 
assessment. Whereas, the second-year students are the subject of this assessment as they will experience learning improvement during their study at school (Kemdikbud, 2020). Then, they also presumed that only the students would participate in the national assessment while the manual book of national assessment stated that all parties including headmasters, teachers, and students would participate in. This finding is connected with the teachers' familiarity on the components of national assessment consisting of minimum competency assessment, character survey, and learning environment survey. The students will take the first two components and the headmasters, teachers and students take the remaining. This research found a misconception that all students would participate in the national assessment. This is an incorrect point of view since only some second-year students who are randomly selected will involve.

Fourth, this study found a misleading regarding the period or schedule of national assessment. The majority of the teachers thought that national assessment would be administered in four days with 120-minute duration for each tested subject. The assessment is planned to finish in two days with 90-minute duration for reading literacy and numerical literacy apiece. The first day is scheduled for reading literacy followed by a 30-minute character survey while in the second day is rostered for numerical literacy and a 30-minute learning environment survey. The students who are selected by the government have to complete 36 questions related to reading competency and numerical competency respectively. Then, this assessment is administered with a computerized-adaptive mode where the students are answering the items based on their level of capability. This mode is suitable for both theoretical and numerical assessment compared to the traditional one (Comas-Lopez, Rubia, \& Sacha, 2018). The students' motivation in finishing all the questions increases as the questions appeared are based on their individual level of competency.

\section{Teachers' Misconception of Follow-up to National Assessment}

Figure 3 presents the teacher's misconception on the follow up to the national assessment. It is clear that $61 \%$ in-service teachers improperly regarded the follow up to the national assessment.
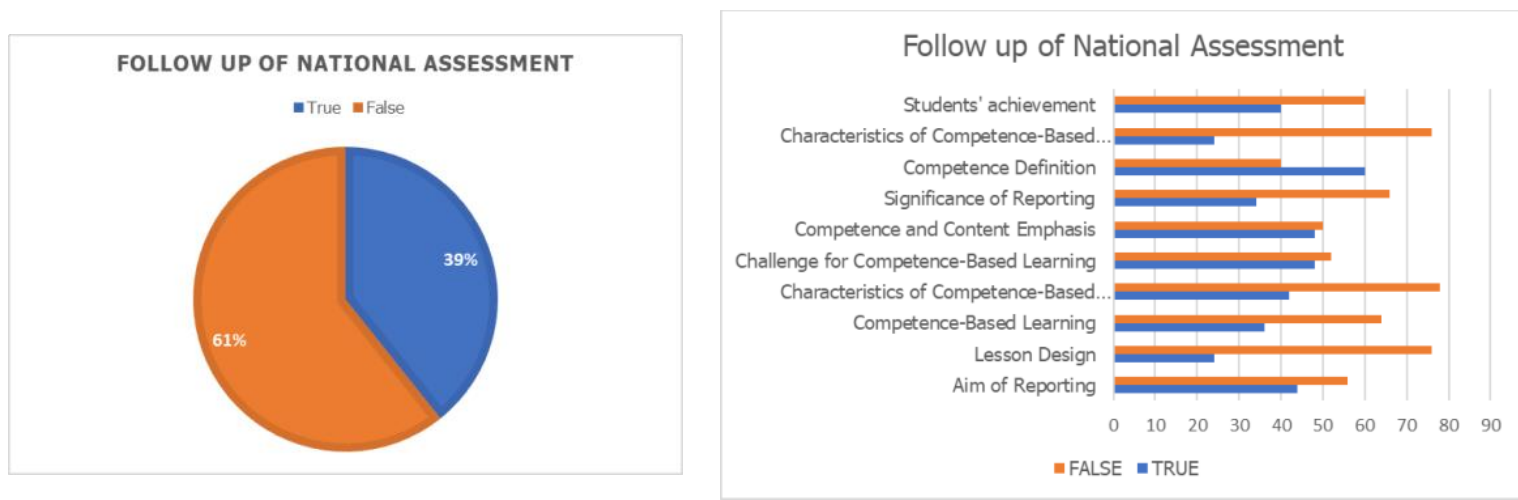

Figure 3. Percentage of national assessment follow up 
In the students' achievement report, the teachers thought that the result was reported in the format of scores like in the national examination. This finding is corresponded with the aim of national assessment reporting. This assessment aims to provide information about the basic general capabilities of the students in reading literacy and numerical literacy. From the result of the report, every education stage could take the significance of the students' minimum competency level which are categorized into four groups as is listed in Table 3 and Table 4 (Kemdikbud, 2020).

Table 2. Report on reading literacy

\begin{tabular}{|l|l|}
\hline \multicolumn{1}{|c|}{ Level } & \multicolumn{1}{c|}{ Description } \\
\hline Need special intervention & $\begin{array}{l}\text { Students are unable to find and take explicit information in the text and create } \\
\text { a simple interpretation. }\end{array}$ \\
\hline Basic & $\begin{array}{l}\text { Students are able to find and take explicit information in the text and create a } \\
\text { simple interpretation. }\end{array}$ \\
\hline Competent & $\begin{array}{l}\text { Students are able to create interpretation and implicit information in the text; } \\
\text { able to draw conclusion as the result of integrated information in a text. }\end{array}$ \\
\hline Proficient & $\begin{array}{l}\text { Students are able to integrate some information inter-texts, evaluate the } \\
\text { content, quality, writing style, and have a reflective attitude towards the text's } \\
\text { context. }\end{array}$ \\
\hline
\end{tabular}

Table 3. Report on numerical literacy

\begin{tabular}{|l|l|}
\hline \multicolumn{1}{|c|}{ Level } & \multicolumn{1}{c|}{ Description } \\
\hline Need special intervention & $\begin{array}{l}\text { Students have limited mathematical knowledge. Students show partial } \\
\text { conceptual mastery and limited computation skill. }\end{array}$ \\
\hline Basic & $\begin{array}{l}\text { Students have basic conceptual mathematics and basic computation in linier } \\
\text { equation, basic concept related to geometry and statistics and are able to solve } \\
\text { the simple routines mathematics problems. }\end{array}$ \\
\hline Competent & Students are able to implement mathematics concept in various contexts. \\
\hline Proficient & $\begin{array}{l}\text { Students are able to reason properly on complex non-routine problem based } \\
\text { on the owned mathematics concept. }\end{array}$ \\
\hline
\end{tabular}

Table 3 describes the report on reading literacy in reading while Table 4 delineates the report on numerical literacy based on the result of Minimum Competency Assessment. From both tables, it is clear that the report of the students' achievement is categorized into four levels. These levels start from the lowest to the highest where the students with limited capacity in reading and Mathematics are grouped into need special intervention level. It means that the students are able to solve the problems related to the context of reading and Mathematics below the threshold or under the minimum circumstances. In this case, the students should be given audio-visual learning resources and they should be given special guidance. The other upward levels indicate that the students have met the passing criteria in minimum competency in reading and Mathematics. They are suggested to be given comparative and reflective learning process in order to achieve the relevant learning resources and contexts. 
Teachers of each subject could take the advantage of those competency levels so as to design the learning strategy which is effective and qualified based on the students' level of achievement. The learning process should be designed by considering those levels so that it will enable the students to master concept, skill, and content expected in a subject.

Next, this study found the teachers' misconception on the sub-topics of competency-based learning versus content-based learning. They regarded that both types of learning were similar each other. The characteristics of competency-based learning are: (1) Emphasis on necessity; (2) Learn for conceptual mastery and skill; (3) Demonstrate performance by applying concept; (4) Real-life contextual learning; and (5) Process and competency mastery-oriented. These characteristics are in line with a study stating that students given multiple chance to improve their performance. When those failing to meet the minimum standard, could demonstrate learning progress and achievement in multiple ways, and are given chances to make important decision about their learning (Weafer \& Costin, 2017). On the other hands, the characteristics of content-based learning are: (1) Emphasis on the topic; (2) Learn for scope of the topic; (3) Testanswering based on the topic; (4) Real-life-disconnected learning; and (5) final-grade-oriented.

In relation to the aim of national assessment, the learning process has to gradually change from a content-based learning to competency-based learning. The advantage of competencybased learning is focused on the flexibility or self-phased learning. Therefore, the teachers need to analyze the level category of their students and link it to reading literacy and numerical literacy. For instance, in an Art class a teacher stimulates the students to read a short passage about wind musical instruments. After reading a passage, the students are asked some questions about what they like or dislike from the passage. Then, every student is instructed to blow their wind instrument and ask why the instrument produces such a sound. When the students close all the holes with their fingers, what kind of sound is produced? and what happens if they gradually lift up their finger from one hole to the entire holes? What happens if the students blow the instrument with certain magnitude of breath flow? The result of the students' feedback is different from one to another and this could be mapped as the competency level of the group of students. The follow up then could be decided based on the students' performance in playing wind instrument. This type of competency-based learning interconnects reading literacy, numerical literacy, and minimum skills in an Art subject.

\section{Conclusion}

The Junior High School in-service teachers experienced misconception on national assessment as the new educational policy in Indonesia. This is supported by the evidence in the finding of this study stating that they were misled with the basic concept of national assessment, technical administration of national assessment and follow up to the result of national 
assessment. In terms of basic concept, the teachers considered that this assessment was implemented to determine the passing criteria of the students, that the students would be demotivated when the aim of national assessment was not used as the passing criteria and that the cognitive aspects tested in national assessment and national examination were similar. In technical administration, the teachers were not familiar with the type of the question, did not know how to design HOTS questions, believed that the final-year students mandatorily took the national assessment, and showed incorrect view regarding the period or schedule of national assessment. In the follow up of national assessment, the teachers thought that the result was reported in the score format like in the national examination and there was misconception on the sub-topics of competency-based learning versus content-based learning. To sum up, most of the teachers considered that national assessment was similar to national examination. These results suggest the reinforcement and empowerment of the schools concerning the socialization and the prototype or simulation implementation of national assessment. For further studies, it is recommended that this cognitive test about the content of national assessment be administered periodically to the teachers before the real assessment is commenced. Then, the teachers' capacity in designing the prototype of reading and numerical literacy must be improved through internal or external workshops.

\section{References}

Akib, E., Imran, M. E., Mahtari, S., Mahmud, M. R., Prawiyogy, A. G., Supriatna, I., \& Ikhsan, M. H. (2020, April). Study on implementation of integrated curriculum in indonesia. IJORER : International Journal of Recent Educational Education, 1(1), 39-57. https://doi.org/10.46245/ijorer.v1i1.24

Alawiyah, F. (2015). Perubahan kebijakan ujian nasional (studi pelaksanaan ujian nasional 2015). Aspirasi: Jurnal Masalah-Masalah Sosial, 6(2), 189-202. https://doi.org/10.46807/aspirasi.v6i2.513

Asrianto, A., Rohmayadevi, L., \& Rokhyati, U. (2020, March). Teacher's strategies in managing the class. Eduvelop: Journal of English Education and Development, 3(2). https://doi.org/10.31605/eduvelop.v3i2.602

Bordens, K. S., \& Abbott, B. B. (2018). Researh design and methods: A process approach, Tenth Edition. New York: McGraw-Hill Education.

Comas-Lopez, M., Rubia, M. A., \& Sacha, G. M. (2018). Adaptive test system for subjects that simultaneously include theoretical content and numerical problem solving. 2018 International Symposium on Computers in Education (SIIE) (hal. 1-5). Jerez: IEEE Explore. 
doi:10.1109/SIIE.2018.8586729

Effendi, T., \& Suyudi, I. (2017). The impacts of English national examination in Indonesia. Ninth International Conference on Applied Linguistics (CONAPLIN 9. 82, hal. 236-239. Atlantis Press. doi:https://doi.org/10.2991/conaplin-16.2017.52

Hadi, A., \& Arwan. (2011). Pro kontra Ujian Nasional (UN) dalam sistem evaluasi pendidikan di Indonesia. Conciencia: Jurnal Pendidikan Islam, 79-92.

Hartanto, S. (2013). Ujian Nasional (UN), masih perlukah? Jakarta: LPPKS.

Hidayati, A., Zaim, M., Rukun, K., \& Darmansyah. (2014, June). The development of character education curriculum for elementary students in West Sumatera. International Journal or Education and Research, 2(6), 189-198.

Iramdan, \& Manurung, L. (2019, April). Sejarah kurikulum di Indonesia . Jurnal Ilmiah Wahana Pendidikan 5(2), 88-95. Diambil kembali dari https://jurnal.unibrah.ac.id/index.php/JIWP/article/view/98

Ismail, H. F. (2015, September). Pro kontra ujian nasional. Al-Riwayah: Jurnal Kependidikan, 7(2), 301-324. Diambil kembali dari http://ejournal.stain.sorong.ac.id/indeks.php/al-riwayah

Kemdikbud. (2020). Lembar tanya jawab asesmen nasional. Jakarta.

Koesoema, D. (2020). Kebijakan ujian nasional dan asesmen nasional. Jakarta.

Kompas. (2020, September 15). Perjalanan ujian nasional dari masa ke masa. Diambil kembali dari Kompas.com: https://www.kompas.com/edu/read/2020/09/15/110837871/perjalanan-ujian-nasionaldari-masa-ke-masa-kamu-ikut-yang-mana?page=all

Kusuma, M. D., Rosidin, U., Abdurrahman, \& Suyatna, A. (2017). The development of higher order thinking skill (Hots) instrument assessment in physics study . IOSR Journal of Research \& Method in Education (IOSR-JRME) , 7(1), 1-7. doi:DOI: 10.9790/7388-070103XXXX

Munthe, N. B. (2020). Opini siswa tentang rencana penghapusan ujian nasional pada tahun 2021 (Studi Kasus Pada SMA NEGERI 2 MEDAN) . Medan: Universitas Muhammadiyah Sumatera Utara.

Nehru, N. A. (2020). Asesmen kompetensi sebagai bentuk perubahan ujian nasional pendidikan Indonesia: Analisis dampak dan problem-solving menurut kebijakan merdeka belajar. Diambil kembali dari https://www.academia.edu/download/62372209/ASESMEN_KOMPETENSI_SEBAGAI_BENT UK_PERUBAHAN_UJIAN_NASIONAL_PENDIDIKAN_INDONESIA20200315-94955-1h4ufc5.pdf

Ningsih, A. W., Shara, A. M., Andriani, D., \& Kisno. (2021, February 6). Reading duration and 
financial literacy in vocational high school. Jurnal Education and Development, 9(1), 577-583. https://doi.org/10.37081/ed.v9i1.2288

Novita, N., Mellyzar, \& Herizal. (2021). Asesmen nasional (AN): Pengetahuan dan persepsi calon guru. Jurnal Ilmu Sosial dan Pendidikan, 5(1), 172-179.

Pernamawati, S., Kritiawan, M., \& Fitria, H. (2021, January). Analisis SWOT ujian nasional berbasis komputer. JMKSP: Jurnal Manajemen, Kepemimpinan, dan Supervisi Pendidikan, 6(1), 112-123.

Ritonga, M. (2018). Politik dan dinamika kebijakan perubahan kurikulum pendidikan di Indonesia hingga masa reformasi. Bina Gogik, 5(2), 88-102.

Romios, L., Kristianingrum, N. P., \& Saragih, N. A. (2020, October). Educational policy: Voices from local English teachers and students towards national exam in Yogyakarta. Metathesis: Journal of English Language Literature and Teaching, 4(2), 217-231. doi:DOI: 10.31002/metathesis.v4.i2.2801

Shara, A. M., Andriani, D., Ningsih, A. W., \& Kisno. (2020, December). Correlating reading literacy and writing literacy in junior high school Pematangsiantar. Journal of English Education (JEE), 5(2), 72-85. https://doi.org/10.31327/jee.v5i2.1249

Sutari, V. R. (2017). National examination in Indonesia and its backwash effects: Teachers' perspectives. Ninth International Conference on Applied Linguistics (CONAPLIN 9). 82, hal. 331333. Atlantis Press. https://doi.org/10.2991/conaplin-16.2017.76

Unicef. (2020). Education and covid-19. New York: Unicef Data.

Weafer, D., \& Costin, M. (2017, July 10). Competency-based education. Portland, Maryland.

Widana, I. W. (2017). Modul penyusunan higher order thinking skill (HOTS). Jakarta: Direktorat Jenderal Pendidikan Dasar dan Menengah Departemen Pendidikan dan Kebudayaan.

Widyatmoko, A., \& Shimizu, K. (2018). An overview of conceptual understanding in science education curriculum in Indonesia. International Conference on Mathematics, Science and Education 2017 (ICMSE2017). 983, hal. 1-6. Semarang: IOP Publishing Ltd.

Yuliati, S. R., \& Lestari, I. (2018). Higher-order thinking skills (Hots) analysis of students in solving hots question in higher education. PERSPEKTIF Ilmu Pendidikan , 32(2), 181-188. doi: https://doi.org/10.21009/PIP.322.10 